\title{
Des-orientar Cleópatra: um tropo moderno da identidade*
}

Ella Shohat**

\begin{abstract}
Resumo
Este artigo propõe um estudo da representação de Cleópatra ao longo do século passado, situando o debate sobre sua aparência $e$ origens no âmbito da dominação colonial, das lutas anti-coloniais $e$ das friç̧ões raciais pós-coloniais que, como se tenta mostrar, acrescenta uma outra dimensão para entender o investimento na identidade de Cleópatra.
\end{abstract}

Palavras-chave: Cleópatra, Gênero, Raça, Pós-Colonialismo.

\footnotetext{
" Publicado em WaLKer, Susan e AsHTon, Sally-Ann. (orgs.) Cleopatra Reassessed. The British Museum Occasional Paper 103, 2003, pp.127-138. A editora dos cadernos pagu agradece a autorização da autora para traduzir este artigo. (Tradução: Plínio Dentzien; Revisão: Iara Beleli.)

** New York University, Nova Iorque, Estados Unidos. es100@nyu.edu
}

cadernos pagu (23), julho-dezembro de 2004, pp.11-54. 
Des-orientar Cleópatra

Disorienting Cleopatra:

A Modern Trope of Identity

\begin{abstract}
This article proposes a study about Cleopatra's representation throughout the last century, situating the debate on her looks and origins among colonial domination, anti-colonial struggles and post-colonial racial frictions that, as it tries to demonstrate, add another dimension towards understanding the investment in Cleopatra's identity.
\end{abstract}

Key Words: Race, Gender, Postcolonialism, Cleopatra. 
O nome "Cleópatra" provoca todo tipo de paixões. Não é a menor delas a que se refere à sua aparência e, por implicação, à questão de suas origens e identidade: como era a antiga rainha? Era assombrosamente bela? Branca ou negra? De ascendência macedônia, grega ou egípcia? Respostas enfáticas e categóricas a essas perguntas sugerem uma hubris científica sobre a possibilidade mesma de chegar à "Verdade Histórica" em geral e, em especial, sobre um domínio cognitivo pleno em relação a Cleópatra e seu mundo. Por mais que a ciência possa buscar a objetividade, a história, como acabamos por reconhecer, envolve não só fatos, mas também narrativas, discursos e visões de mundo. Ao contrário de um certo pós-modernismo, entretanto, este ensaio não professa à maneira niilista a impossibilidade de acesso a qualquer "fato" ou "verdade" (em minúsculas mesmo). Em meu trabalho, tenho tentado investigar como são estabelecidos os fatos, como são justapostos a outros fatos, $e$ narrados como parte de um complexo narrativo mais amplo. Fragmentário e situado, o conhecimento científico deve fundar-se em parte na interpretação e na "leitura" dos fatos. Qualquer olhar sobre o passado, nessa conjuntura, deve ser correlacionado a questões de visões de mundo $e$ aos discursos compartilhados pelos "leitores" da história. ${ }^{1}$

Examino aqui alguns textos contemporâneos que tentam dissipar o mistério que cerca a aparência $e$ as origens de Cleópatra. Enfrentar o tema Cleópatra envolve quase necessariamente perguntar sobre a construção da imagem $e$ a representação visual. Durante milênios, sua história de amor e de morte, de poder e sexualidade, de dominação e subordinação, $e$ do intercurso imperial entre as civilizações grega, egípcia $e$ romana, tem excitado a imaginação popular, provocando opiniões apaixonadas sobre sua aparência e origens. O histórico e

\footnotetext{
1 Ver SHOHAT, Ella e STAM, Robert. Unthinking Eurocentrism. Londres, Routledge, 1994. Este ensaio supõe a definição do conceito de eurocentrismo como aparece nessa obra.
} 
Des-orientar Cleópatra

o fantástico se alimentaram mutuamente. A incerteza sobre sua aparência, contudo, permitiu a cada geração dar a ela uma imagem na forma de seus desejos. Cada época, pode-se dizer, tem sua própria Cleópatra, a ponto de se poder estudar o pensamento e discursos de uma época através de suas fantasias sobre Cleópatra. A antiga rainha, portanto, constitui mais que uma figura histórica que poderia ser relegada aos domínios da arqueologia e da egiptologia; antes, ela constitui uma alegoria de questões altamente carregadas relativas à sexualidade, gênero, raça $e$ nação, questões que vão muito além do espaço geo-cultural de seu tempo. Em termos gerais, estudarei a representação de Cleópatra ao longo do século passado, à medida que se misturava com o auge do imperialismo, assim como com o surgimento subseqüente das nações pós-coloniais e suas diásporas. Situar o debate sobre sua aparência e origens no âmbito da dominação colonial, das lutas anti-coloniais e das fricções raciais póscoloniais, como tentarei mostrar, acrescenta uma outra dimensão para entender o investimento na identidade de Cleópatra.

Contudo, para enfrentar em profundidade os debates contemporâneos sobre Cleópatra, é preciso levar a sério sua representação na cultura popular. Escrito no marco dos Estudos Culturais, este ensaio insiste na importância de "ler" Cleópatra dentro da modernidade, e especialmente no contexto das tecnologias dos meios de massa. A partir do final do século dezenove, Cleópatra surgiu como uma figura dos meios de massa. Ela tem sido visualizada, evocada e referida em numerosas fotografias, cartões postais, filmes, anúncios, comerciais, séries de televisão, revistas de moda e sítios na internet. Recentemente, por exemplo, Cleópatra apareceu na série futurista de televisão 2525 , onde uma exótica dançarina chamada Cleópatra, congelada em 2001, desperta cinco séculos mais tarde e luta corajosamente para resgatar a terra, controlada por criaturas malvadas conhecidas como Bailies, para a humanidade. $\mathrm{O}$ advento das várias tecnologias de comunicação de massa - filme, televisão, vídeo $e$ digital - não diminuiu a paixão pela antiga rainha. A indústria da 
construção da imagem de Cleópatra alcançou notável disseminação global, a ponto de sua imagem ter se infiltrado nos lares nas geografias culturais mais diversas.

\section{Cleópatra entre o eurocentrismo e o afrocentrismo}

A avó de Cleópatra era uma concubina; sua mãe não é conhecida. Dadas as incertezas de sua ascendência, um pesquisador estimou que seu sangue tinha 32 partes de grego, 27 partes de macedônio e 5 partes de persa. É uma estimativa razoável. Se era negra, ninguém o mencionou. ${ }^{2}$

Ao longo das últimas décadas, Cleópatra foi tema de aceso debate sobre sangue, raça e origens. Embora muitos textos reconheçam a impossibilidade de estabelecer plenamente suas origens, a maioria dos autores continua a fazer afirmações fortes. Investimentos científicos e artísticos numa particular aparência de Cleópatra sugerem que sua figura se transformou num lugar metafórico das lutas raciais contemporâneas, especialmente no "Ocidente" pós-colonial. Dentro da geografia da modernidade, as cansadas dicotomias Oriente contra Ocidente, África contra Europa, e Negro contra Branco continuam a informar o modo como as civilizações antigas são diacriticamente construídas. Estabelecer que ela foi negra, africana e egípcia, de um lado, ou que foi branca, greco-macedônia e européia, de outro - é visto como um tento para cada um dos lados nas "guerras culturais". Visíveis nos meios de comunicação de massa, esses debates carregados misturaram-se muitas vezes com o enfrentamento relativo ao surgimento do afrocentrismo como campo acadêmico. Em 1991, por exemplo, Newsweek dedicou algumas páginas à questão da negritude de Cleópatra como parte de sua revisão do destaque afrocêntrico das realizações africanas em termos de civilização. O projeto afrocêntrico re-situou o Egito no terreno da

2 Foss, Michael. The Search for Cleopatra. Nova Iorque, Arcade Publishing, 1987. 
Des-orientar Cleópatra

civilização africana, argumentando que o Egito fora "roubado" da África, e situado no oriente próximo por eruditos do século dezenove cujo racismo os impedia de creditar realizações monumentais como a construção das pirâmides aos africanos. A posição geral da Newsweek deixava implícito que tais reivindicações afrocêntricas, e particularmente aquelas que afirmavam que a civilização européia em realidade derivava da África, eram ignoradas ou negadas pelos pesquisadores ocidentais. A revista concluía com um quadro de perguntas e respostas que perguntava se os egípcios eram negros e respondia que o Egito era o lar de negros, asiáticos e semitas, mas que Cleópatra "era provavelmente grega". Embora aceitasse a negritude parcial do Egito, a matéria da Newsweek parece sugerir, à maneira eurocêntrica, que a civilização grega evita a questão negra, ou, mesmo, que "grego" implica automaticamente "brancura".

O debate sobre a tonalidade da pele de Cleópatra nos meios de comunicação tem tudo a ver com contestações multiculturais sobre currículo, pedagogia e historiografia. O que está em jogo no debate sobre Cleópatra é saber se o ensino de história pode ser questionado e revisto, ou apenas padronizado da maneira usual. A disputa sobre se Cleópatra é branca ou negra não pode, assim, ser examinada simplesmente no domínio da Antigüidade, mas deve também ser vista dentro do contexto colonial e de suas conseqüências. $\mathrm{O}$ investimento contemporâneo na negritude de Cleópatra, em que ela era egípcia e africana, está em oposição dialética à insistência prévia em sua brancura, e em que ela era grega e européia. Ao longo dos últimos séculos, inúmeras obras de arte, representações populares e relatos historiográficos supuseram $e$ até afirmaram sua brancura. Autores como Jack Lindsay derivam sua ascendência dos Ptolomeus do Egito. ${ }^{4}$ Para Lindsay, Cleópatra tinha principalmente "sangue macedônio", embora ele admita que restam algumas perguntas sobre a etnia de sua avó.

3 Was Cleopatra Black? Newsweek, 23 de setembro, 1991, esp. pp.42, 44.

4 LindSAY, J. Cleopatra. Londres, Constable, 1971, pp.2-4. 
Ao mesmo tempo, Lindsay contesta qualquer argumento de que a avó de Cleópatra fosse egípcia, quando escreve que "ela não tinha sangue egípcio". Sua posição se apóia na suposição de que apenas um Ptolomeu tivera uma amante egípcia, e em geral as amantes dos Ptolomeus eram gregas. Acrescenta, ainda, que não estamos certos sobre a identidade da mãe de Cleópatra, e também discorda da suposição de que Cleópatra era filha de uma "amante não nomeada". Como Cleópatra nunca foi "insultada" por ser filha de uma concubina, mesmo durante "as furiosas acusações e insultos de seus últimos anos", Lindsay conclui que sua mãe deveria ter sido "casada" com seu pai Ptolomeu XII.

$\mathrm{O}$ autor de outra biografia de Cleópatra, Michael Grant, também acredita que, embora Cleópatra tivesse vivido e reinado no Egito, ela não tinha "uma gota de sangue egípcio em suas veias". ${ }^{5}$ Como uma Ptolomeu, foi criada como grega, $e$ era também "em boa medida de raça grega". Também levanta a questão da identidade da mãe de Cleópatra, concluindo que ela deve ter sido Cleópatra V Trifaena - a primeira esposa de seu pai. Grant rejeita a possibilidade de que uma amante pudesse ter sido a mãe na mesma base que Lindsay; é pouco provável que ela fosse filha ilegítima, porque a propaganda romana negativa nunca o mencionou. Ainda que insista em que Cleópatra não tinha "sangue egípcio", Grant sugere que ela era racialmente mista e bem "escura", fato que atribui a seus ascendentes macedônios que "tinham sangue muito misturado". Conclui que, embora os "ingredientes raciais" da identidade Macedônia de Cleópatra possam ter sido misturados, culturalmente ela era inteiramente grega. Em seu livro From Alexander to Cleopatra, contudo, Grant faz uma descrição de costumes que sugere que os gregos freqüentemente tomavam mulheres egípcias como amantes. "Quando os gregos iam para além-mar como colonos", escreve,

5 Grant, M. Cleopatra. Londres, Simon Schuster, 2001 [1972], esp. pp.xiii, 4, 5. 
Des-orientar Cleópatra

"muitas vezes não levavam suas esposas e famílias". ${ }^{6}$ Observa, ademais, que embora as mulheres não pudessem manter relações extraconjugais, aos homens "era permitido o adultério eventual, especialmente com escravas e prostitutas". Ainda que o próprio Grant não tire essa conclusão, seu relato sugere a ocorrência de "mistura racial" não só na Macedônia, mas também no Egito, fato com implicações significativas para os discursos sobre a constituição étnica e racial de Cleópatra.

Alguns textos, no entanto, trouxeram para o primeiro plano a possibilidade das origens mistas de Cleópatra. Sarah B. Pomeroy, por exemplo, descreve Cleópatra como uma anomalia entre os romanos, por não caber exatamente em nenhuma categoria. ${ }^{7}$ A sociedade romana fazia uma distinção importante entre as mulheres de classe, que serviam para casar, e as cortesãs, mas como Cleópatra "vinha como as cortesãs do oriente helenizado" era chamada de modo um tanto paradoxal de "regina meretrix" (rainha meretriz). Além disso, os Ptolomeus tomaram egípcias como amantes, observação levantada por Pomeroy, mas em geral negada por escritores como Grant $e$ Lindsay. Pomeroy descreve uma situação em que um grego "chegando ao Egito sem amigos nem parentes naturalmente desenvolveria afeição por sua concubina escrava e pelos filhos que tivesse com ela". Em geral, os gregos no Egito não conseguiam esposas gregas e assim "casavam-se com nativas ou tomavam escravas estrangeiras como concubinas". A miscigenação greco-egípcia, em outras palavras, deve ter ocorrido no Egito desde que os senhores de escravos tiveram filhos com suas escravas egípcias. Na mesma direção, Alan Cameron conta a história de uma concubina negra, Didyme, uma amante real de origens etíopes, cuja beleza foi cantada no

6 ID. From Alexander to Cleopatra: the Hellenistic World. Londres, Simon Schuster, 1982.

7 POMEROY, Sarah B. Women in Hellenistic Egypt: From Alexander to Cleopatra. Detroit, Wayne State University Press, 1990. pp.27 (regina meretrix), 55 (Didyme); 132 (gosto grego por concubinas), 137 (casamentos). 
poema de Asclepiades. ${ }^{8}$ Embora casamentos entre gregos e egípcias não fossem aceitos socialmente, como mostra o caso de Didyme, uniões entre "nativas" e gregos aconteciam, mesmo nas camadas sociais mais altas. Segundo Cameron, passou desapercebido em geral que um dos reis Ptolomeus (Ptolomeu Filadelfo) tinha uma amante "nativa", isto é, egípcia. A despeito desses relatos informados da sociedade egípcia permeada do hibridismo racial/étnico, persiste a paixão por uma Cleópatra branca. O recente documentário Cleopatra's World [O Mundo de Cleópatra] (History Channel, 2001), por exemplo, entrevistou Margaret George, autora de The Memoirs of Cleopatra [As Memórias de Cleópatra], que afirmou categoricamente que "Cleópatra não tinha sangue egípcio e, portanto, não podia ser negra".

O debate sobre a cor da pele de Cleópatra foi atravessado, previsivelmente, pelo debate sobre Black Athena [Atenas Negra], de Martin Bernal, a respeito da invenção iluminista da Grécia clássica como puramente "européia". Embora a obra de Bernal não faça referência a Cleópatra, a mídia a trouxe para o banco das testemunhas. Numa matéria da New Republic em 1992, Mary Lefkowitz tentou desacreditar parcialmente o argumento de Bernal ligando-o aos afrocêntricos, inclusive na afirmação de que Cleópatra era negra. Para reforçar seu argumento, ela conta que, numa exibição de Cleopatra na série de filmes antigos, um estudante se ofendeu com a escalação de uma atriz branca Elizabeth Taylor - para o papel de Cleópatra, que o estudante acreditava que fora negra. Em resposta, Lefkowitz afirma, de modo condescendente, que

8 Cameron, Alan. Two Mistresses of Ptolemy Philadelphus. In: Greek, Roman and Byzantine Studies. Durham, Duke University Press, outono 1990, pp.288 (cor da pele), 289 (Didyme). Asclepiades escreveu o seguinte poema dedicado a Didyme: "Que ela seja negra, e daî? Também os carvões. Mas quando os aquecemos, brilham como botões de rosas". 
Des-orientar Cleópatra

fez o melhor possível para persuadi-lo de que, com base na ascendência de Cleópatra (e de seu nome), ela era membro da dinastia greco-macedônia que se impusera no Egito, e que, a despeito de sua fluência na língua egípcia, do estilo de suas roupas, e do luxo de sua corte, ela era grega de origem. ${ }^{9}$

Lefkowitz parece aqui negar categoricamente qualquer possibilidade mesmo parcial de ascendência egípcia e/ou negra de Cleópatra, possivelmente derivada não só do Egito, mas da Grécia $e$ da Macedônia. Sua negação descarta a evidência literária $e$ arqueológica da presença de negros da África Central em várias sociedades do mundo greco-romano. ${ }^{10}$ Mesmo os que insistem em que Cleópatra era plenamente greco-macedônia reconhecem certo hibridismo racial na Macedônia. Assim, mesmo que suponhamos que Cleópatra "não tinha uma só gota de sangue egípcio", seria difícil rejeitar categoricamente toda e qualquer mistura em sua linhagem e, por implicação, uma certa contribuição da posição afrocêntrica.

Ao mesmo tempo, o que é notável no debate - tanto no discurso eurocêntrico quanto no afrocêntrico - é a maneira como a categoria raça como marcador biológico se confunde com as de etnia e nacionalidade como sintomas de filiação geográfica, social e cultural. De muitas maneiras, portanto, as afirmações opostas de que Cleópatra era egípcia, e portanto negra, e de que era grega, e portanto branca - são igualmente problemáticas. Tanto a equação simplista entre, de um lado, ser egípcia e negra, quanto, de outro, ser grega e branca, essencializam geografias culturais. Supor a brancura de Cleópatra implica desconsiderar o que mesmo autores como Grant, que insiste que Cleópatra era grega, reconhecem - o fato de que os macedônios eram racialmente

9 LefKowitz, Mary. Not Out of Africa. New Republic, 1992, p.30.

${ }^{10}$ Ver SNOWDEN JR, Frank M. Blacks in Antiquity: Ethiopians in the Greco-Roman Experience. Cambridge, Mass., The Belkamp Press of Harvard University Press, 1970, p.2. 
muito misturados. Ambas as posições, de modo semelhante, parecem negligenciar a mistura do outro lado - entre os egípcios. $\mathrm{O}$ investimento eurocêntrico na pura brancura de Cleópatra e a insistência afrocêntrica em sua pura negritude se espelham mutuamente. Mais recentemente, a questão da hibridez também entrou no debate sobre a obra de Bernal. Em 2001, no Times Literary Supplement, Bernal se alinha com e se distancia de algumas posições afrocêntricas. Em resposta a Lefkowitz, escreve:

Lefkowitz dá grande ênfase ao que considera minha proximidade ao afrocentrismo. É verdade que respeito a adesão dos afrocêntricos por quase duzentos anos à sua própria versão do Modelo Antigo, sustentando que os antigos egípcios eram negros, diante do menosprezo não só da academia branca mas também de negros que se acomodaram a ela. Isso não significa que eu aceite algumas das posições mais fortes defendidas por alguns deles, por exemplo que Cleópatra era negra ou que a melanina é necessária à criatividade. ${ }^{11}$

Referindo-se a Cleópatra apenas uma vez nesse debate, Bernal chega a sugerir o hibridismo tanto do Egito quanto da Grécia. Em alguns aspectos, observa, os argumentos de Lefkowitz estão mais próximos do afrocentrismo que os seus próprios. Lefkowitz compartilha com a maioria dos afrocentristas a visão da "africanidade do Egito", pois ambos objetam à noção da "mistura de culturas a partir de continentes diferentes". "O que é anátema para Mary Lefkowitz é a afirmação feita em Black Athena de que 'a glória da Grécia' resultou de hibridez intercontinental".

O debate sobre a identidade de Cleópatra, como vimos, supõe brancura e negritude como uma polaridade inescapável, desprovida de tonalidades intermediárias, projetando Grécia e Egito como espaços racialmente puros. Assim, à afirmação

${ }^{11}$ BERNAL, Martin. Black Athena is the Ancient Model. TLS, 11 de maio de 2001, p.10. 
Des-orientar Cleópatra

enfática de Michael Foss de que "se Cleópatra era negra, ninguém o mencionou", podemos responder - se Cleópatra era branca, ninguém tampouco o mencionou. A "demonstração" da brancura de Cleópatra muitas vezes proclama a falta de referência a sua negritude na campanha negativa romana contra Cleópatra. O argumento supõe de maneira simplista que a negritude era uma característica negativa nos discursos romanos. No entanto, como alguns autores mostraram, o mundo greco-romano não era assolado pelos mesmos preconceitos de cor que afligem o mundo moderno. ${ }^{12} \mathrm{~A}$ invocação da propaganda romana contra Cleópatra como evidência de sua brancura se baseia ainda em outras suposições problemáticas: que os romanos sabiam tudo o necessário sobre as práticas sexuais de todos os macedônios antes de sua chegada ao Egito, e de cada um dos membros da dinastia dos Ptolomeus no Egito durante os três séculos que separam a conquista do Egito por Alexandre e o nascimento de Cleópatra; que qualquer desses relatos, especialmente da "história oficial", pode garantir o conhecimento da pureza racial não só de Cleópatra, mas de qualquer indivíduo; que os conceitos de negritude e brancura ao tempo de Cleópatra carregavam as mesmas conotações negativas e positivas dos discursos racializados da Europa surgidos durante a colonização das Américas, da África e da Ásia; que a definição de brancura $e$ negritude como marcadoras de identidade no antigo Mediterrâneo

\footnotetext{
${ }^{12}$ Segundo Frank M. Snowden Jr muitos classicistas e antropólogos notaram a ausência de preconceito de cor no mundo greco-romano: J. Brice observou que no Império Romano ouve-se pouco sobre qualquer repugnância aos africanos de pele escura; E. Baring, que a antipatia por causa da cor não impedia o intercurso social na antiguidade; E. E. Sikes, que os antigos pareciam livres de preconceito de cor; A. Zimmern, que os gregos não mostravam preconceito; W. L. Westermann, que a sociedade grega não tinha divisões de cor; T. J. Haarhoff, que nunca houve preconceito de cor na Itália; Kluckhohn, que os gregos não caíram no erro do racismo biológico, que a cor não era estigma, que os homens não eram classificados como brancos ou negros, mas como livres e escravos; $\mathrm{e} \mathrm{H}$. C. Barry, que os gregos foram poupados da moderna maldição do preconceito de cor. Ver SNOWDEN JR, F. M. Blacks in Antiquity... Op. cit., p.169.
} 
teve profundo impacto sobre a filiação cultural e a estatura social na medida em que precisava da identificação dos indivíduos como brancos ou negros; que o conteúdo e o significado de brancura e negritude no antigo Mediterrâneo podem ser estabelecidos dentro de claras dicotomias raciais; que negritude e brancura mantiveram um sentido fixo ao longo de milênios; que a definição de egípcio ao tempo de Cleópatra significava necessariamente ser negro; $e$ que a definição de grego significava necessariamente ser branco.

O descarte eurocêntrico da possível negritude de Cleópatra levanta questões de natureza semelhante às que podem ser levantadas em relação à insistência afrocêntrica em sua negritude. Que paradigmas serviriam para definir negritude e brancura como categorias biológico-raciais? Seria meramente uma questão visual, isto é, tom da pele, características faciais, qualidade do cabelo e outras características físicas? Ou incluiria também certa quantidade de sangue, mesmo na falta de traços (brancos ou negros) visíveis e detectáveis a olho nu? A adoção de tal referencial discursivo exigiria certo número de procedimentos científicos: determinar a quantidade de melanina necessária para marcar a fronteira entre brancura e negritude; desenhar uma representação científica de diversas características - nariz, lábios, cabelos - indicadoras de negritude e brancura; fazer uma medição sistemática da quantidade de "sangue" branco e negro e de órgãos pouco visíveis, por exemplo, o cérebro, para determinar a formação racial de uma pessoa nos casos em que a "verdade racial" pode escapar aos atentos cientistas; mensurar e ordenar os vivos e os mortos a fim de produzir um mapa global capaz de delinear a separação genealógica das raças. Em uma palavra, a tentativa de forjar uma Cleópatra puramente branca ou negra não nos mandaria de volta para a antiguidade, mas para os discursos raciais do século dezenove, cujo essencialismo biológico teria então que ser estendido retroativamente à antiguidade. No século dezenove, o racismo eurocêntrico obteve a aura associada à ciência como conhecimento "objetivo" livre da mancha do subjetivo e do contingente. A mesma época assistiu ao nascimento 
Des-orientar Cleópatra

do racismo biológico; antigos preconceitos receberam o selo da ciência. O determinismo biológico argumentava que as diferenças sócioeconômicas entre raças, classes e sexos eram produto de traços genéticos herdados; o social era um epifenômeno da biologia. A decadência era atribuída à mistura das raças; o "mestiço" tornou-se a personificação da dialética de império $e$ emancipação, e era temido pelos racistas como um monstro, um híbrido infértil. $\mathrm{O}$ sangue e a genética sobredeterminaram a cultura européia no século dezenove, policiando as fronteiras da identidade contra a fluidez anárquica dos intercâmbios raciais $e$ sexuais.

As discussões dicotômicas contemporâneas da identidade de Cleópatra reproduzem assim o racismo científico e a codificação legal que constituem um dos traços mais repugnantes do discurso colonial. Para classificar a herança racial de Cleópatra segundo a quantidade de melanina visível a olho nu, a identidade dela teria que ser definida em termos de proporção de sangue: quanto sangue negro seria necessário para determinar sua negritude $-1 / 8$, ou uma simples gota? Podemos agora invocar tais categorias de sangue para determinar a formação racial de populações antigas num espaço mediterrâneo caracterizado por milênios de misturas de povos e culturas dos continentes da África, Ásia e Europa - isto é, numa região onde a mistura teve lugar antes, durante e depois da época de Cleópatra? O descarte categórico não só da negritude da pele de Cleópatra, mas também da possibilidade de qualquer traço de negritude em seu "sangue" - da Macedônia, do Egito, ou de ambos - levanta questões adicionais que dizem respeito à relação entre antiguidade e modernidade. Mais que um projeto da antiguidade, a determinação da raça de Cleópatra em termos exclusivistas constitui, em minha opinião, um projeto da modernidade. 
Ella Shohat

\section{Retorno ao sincretismo mediterrâneo}

No discurso colonialista, metáforas, tropos e motivos alegóricos desempenharam um papel constitutivo na "figuração" da superioridade européia. Desempenharam também um papel crucial, ainda que contraditório, na construção de hierarquias eurocêntricas. Embora os tropos possam ser repressivos, um mecanismo de defesa contra o sentido literal, eles também constituem uma arena de contestação; cada um está aberto à perpetuação, à rejeição ou à subversão. $\mathrm{O}$ tropo da luz/escuridão, por exemplo, sublinha o ideal iluminista da clareza racional. Imagina mundos não europeus como menos luminosos, donde a idéia da África como "continente negro" e dos asiáticos como "povos do crepúsculo". Antigos maniqueísmos religiosos do bem e do mal se transformam no binarismo filosófico de racionalidade $e$ luz contra irracionalidade e escuridão. O olhar e a visão são atribuídos à Europa, enquanto que os de fora do continente são caracterizados como vivendo na "obscuridade", cegos ao conhecimento racional e moral. Cor, pele e mesmo hierarquias climáticas surgem, privilegiando a luz e o dia em relação à escuridão e à noite, a pele clara em relação à escura, e os climas temperados em relação aos tropicais. ${ }^{13} \mathrm{~A}$ idéia de raça pode ser vista menos como uma realidade do que como um tropo; um tropo da diferença. ${ }^{14}$ Além da associação de "raça" com metáforas de pedigree e de criação de cavalos, "raça" também figura o exagero sistemático: as pessoas não são literalmente pretas, vermelhas, brancas ou amarelas, mas exibem um amplo espectro

\footnotetext{
${ }^{13}$ De modo um tanto contraditório, não é o Mediterrâneo de céus claros, mas o frio e nublado norte que constitui o lugar da racionalidade e da moralidade, enquanto que a selva e o deserto são vistos como lugares intricados do impulso violento e do desejo anárquico. E todos esses binarismos que refletem o id contra o super-ego na escala das civilizações são projetados sobre outros: são/insano; puro/impuro; razoável/histérico; saudável/doente.

${ }^{14}$ Ver também GATES JR, Henry Louis. Figures in Black. Nova Iorque, Oxford University Press, 1988.
} 
Des-orientar Cleópatra

de tons nuançados. É interessante que Hollywood tenha tornado literais esses tropos, pintando atores e atrizes com cosméticos vermelhos, pretos, marrons ou amarelos, sem aplicar a cor branca ao branco, deixando assim a brancura como norma não assinalada. Além disso, a noção das cores como claramente distintas é em si mesma um tropo; de fato, algumas pessoas "pretas" são mais claras que algumas pessoas "brancas". Um tropo cognato, como vemos nos discursos sobre Cleópatra, é a noção de "sangue" racial, que serviu historicamente para significar classe ("sangue azul"), raça ("sangue negro") ou filiação religiosa ("sangue judeu"). Mas a natureza figurada do "sangue" não impediu que o exército norte-americano, durante a segunda guerra, segregasse o plasma do sangue "negro" do plasma do sangue "branco". Ansiedades sobre outros tipos de misturas, sobre a troca de outros fluidos e cores foram projetadas num sangue que nunca deixou de ser vermelho. A despeito de sua natureza quase fictícia, os tropos raciais exercem assim influência real no mundo.

A representação da cor da pele de Cleópatra e o estabelecimento de sua identidade, como vimos, envolve uma construção particular da raça dentro de seu espaço geo-cultural. O discurso dicotômico sobre sua identidade racial depende da maneira como são imaginados a Grécia e o Egito. A identidade de Cleópatra está presa na luta sobre as "verdadeiras origens" da "História" e da "Civilização" - entre a afirmação eurocêntrica da Grécia como ponto de origem e a afirmação afrocêntrica do Egito. Mas a afirmação do início da história na Grécia ou no Egito, isto é, numa certa localização, é problemática em si mesma, uma vez que a história do mundo não tem um único ponto de origem. ${ }^{15}$

${ }^{15}$ É interessante que alguns antropólogos físicos especulam que o primeiro ser humano foi africano e mulher. Ver JOHANSON, Donald e EDEY, Maitland. Lucy: the beginnings of Humankind. Nova Iorque, 1981. Comentadores etíopes da região onde Lucy foi "descoberta" criticaram a escolha de um nome europeu (escolha provocada pela canção dos Beatles "Lucy in the Sky with Diamonds"). A cineasta afro-americana Alice Sharon Larkin observa que se estivesse fazendo um documentário sobre "Lucy", a teria chamado "como as crianças etíopes a chamavam - Maravilhosa", e faria mulheres etíopes contemporâneas falarem 
Mesmo durante o período clássico, a história se desenrolava em volta do globo, na China, no Vale do Indo, na Mesopotâmia, na África, no que hoje chamamos de Américas, e em verdade onde existissem seres humanos. Mais que da "Era" Antiga, deveríamos falar das "Eras" Antigas. ${ }^{16}$ Nesse sentido, afirmar uma versão alternativa, afrocêntrica, da história, ainda que em certo nível reproduza a lógica da história centrada, noutro nível a inverte e, dado o legado negativo do preconceito anti-africano, reafirma um passado genealogicamente produtivo. Aqui o "começo" da consciência política é menos importante que as "origens" da civilização, com debates sobre a Grécia e o Egito como batalhas por prestígio cultural. Os problemas da origem se entrelaçam com a genealogia política da identidade na diáspora.

Em termos históricos e discursivos, o advento do colonialismo inspirou uma re-escrita retroativa da história africana e de sua relação com a civilização grega clássica. A história foi refeita para conformar-se às normas colonialistas, em nome de um eterno "Ocidente" único desde o momento de sua concepção. Continentes inteiros foram tornados eternos "continentes escravos". Bernal descreve o processo em relação à África em Black Athena:

Se fora cientificamente "demonstrado" que os negros eram biologicamente incapazes de civilização, como seria possível explicar o Antigo Egito - inconvenientemente localizado no continente africano? Havia duas, ou talvez três soluções. A

sobre ela. Ver LARKIN, Alice Sharon. Black Women Filmmakers Defining Ourselves: Feminism in our own Voice. In: PRIBRAM, Deidre. (org.) Female Spectators. Londres, Verso, 1988, p.16.

${ }^{16}$ Como sugere Samir Amin, as Américas são salpicadas de ruínas antigas, com as pirâmides e acrópoles da Meso-América e a "Ilha das Tartarugas", mas a educação eurocêntrica raramente chama a atenção para elas. Quem nos diz se a arquitetura monumental do Peru existiu antes de Stonehenge? Ou que, quando a Grécia antiga caía diante da hegemonia de Roma, a cultura nativa americana de Adena já florescia por mais de mil anos? Ver STANNARD, David E. American Holocaust, Nova Iorque, Oxford, 1992, p.41. 
Des-orientar Cleópatra

primeira era negar que os antigos egípcios tivessem sido negros; a segunda, negar que os antigos egípcios tivessem criado uma civilização; a terceira, garantir-se duplamente negando as duas coisas. A última foi a preferida pela maioria dos historiadores dos séculos dezenove e vinte. ${ }^{17}$

Bernal distingue entre o "modelo antigo", que simplesmente supunha a profunda dívida da civilização grega clássica tanto em relação às civilizações africanas (egípcia e etíope) quanto em relação às semitas (hebraica e fenícia) - e o "modelo ariano" que se desenvolveu na esteira da escravidão e do colonialismo. $\mathrm{O}$ modelo ariano teve que fazer engenhosas acrobacias para "purificar" a Grécia clássica de todas as "contaminações" africanas e asiáticas. Tinha que explicar, por exemplo, as inúmeras homenagens gregas a culturas afro-asiáticas, a descrição de Homero dos "irrepreensíveis etíopes", o casamento de Moisés com a filha de Kush, $e$ as freqüentes referências aos "kalos kaghatos" (bons e belos) africanos na literatura clássica. ${ }^{18}$

A repugnância à idéia da possível africanidade de Cleópatra está enraizada num discurso eurocêntrico que degradou sistematicamente a África como deficiente segundo os próprios critérios arbitrários da Europa (a presença de uma arquitetura monumental, da cultura letrada) e de suas hierarquias (melodia acima da percussão, tijolos acima de taipas, roupas acima de decorações corporais). Mas, mesmo para esses padrões dúbios, a África pré-colonial era claramente um continente de cultura rica e diversificada - cenário de altas realizações materiais (ver as ruínas do Zimbabwe), amplos intercâmbios comerciais, complexos sistemas sociais e de crenças religiosas, e diversificadas formas de escrita (pictogramas, ideogramas, escritas objeto como alele $e$

${ }^{17}$ Bernal, Martin. Black Athena. New Brunswick, Rutgers, 1987, p.241.

${ }^{18}$ Frank Snowden documenta contatos entre os africanos de Kush e os egípcios, sírios, gregos e romanos a partir do terceiro milênio antes de Cristo em seu Before Color Prejudice: the Ancient View of Blacks. Cambridge, Harvard University Press, 1983. 
ngombo). Pesquisadores também estabeleceram a complexidade do conhecimento astronômico dogon: o ritual sigui, introduzido pelo mítico ancestral dos dogon, Dyongu Seru, foi considerado análogo ao ciclo orbital da estrela Sirius B. ${ }^{19} \mathrm{E}$ o mouro espanhol Leo Africanus, escrevendo no começo do século dezesseis, descreveu a "magnífica e bem equipada corte" do rei de Timbuktu, e a "grande quantidade de médicos, juízes, sacerdotes e outros sábios... generosamente mantidos a expensas do rei". ${ }^{20}$

A idéia de que a Europa é a Europa, a África é a África, e nunca estarão de acordo, é um mito. Houve considerável contato entre a África e a Europa ao longo dos séculos, e o estado relativo de desenvolvimento dos dois continentes, antes de 1492, era aproximadamente igual. A África tinha uma economia diversificada e produtiva, com fortes indústrias metalúrgicas $e$ têxteis. Os africanos desenvolveram trabalhos em ferro $e$ tecnologia de fornos antes de 600 a.C., prefigurando técnicas utilizadas na Europa só no século dezenove. ${ }^{21}$ No início do século XVII, as exportações de têxteis do Congo Oriental eram equivalentes às de centros europeus de manufaturas têxteis como Leiden. De fato, nos primeiros anos de comércio atlântico, a Europa tinha pouco a vender que a África já não produzisse. ${ }^{22} \mathrm{~A}$ "inferioridade" da África e do africano foi, então, uma invenção ideológica. Ela exigiu "da consciência histórica ocidental a erradicação do significado da Núbia para a formação do Egito, do Egito no desenvolvimento da civilização grega, da África para a Roma Imperial, e mais agudamente da influência do Islã sobre a

\footnotetext{
${ }^{19}$ Rouch filmou o ritual em 1967 no filme La Caverne de Bongo (1969). V. Y. Mudimbe resume alguns dos debates sobre os dogon em The Invention of Africa. Blomington, Indiana University Press, 1988.

${ }^{20}$ Africanus, Leo. History and Description of Africa apud Killingray, David. A Plague of Europeans. Middlesex, 1973, pp.12-13.

${ }^{21}$ THORnTon, John. Africa and Africans in the Making of the Atlantic World 14001680. Cambridge University Press, 1992, pp.43-71, esp. 46.

22 RoBinson, Cedric. Black Marxism. Londres, Palgrove Macmillan, 1983, p.4.
} 
Des-orientar Cleópatra

história econômica, política e intelectual da Europa". ${ }^{23} \mathrm{O}$ que importa aqui não é cumprimentar a África por "satisfazer" os critérios competitivos eurocêntricos de "civilização". Mas chamar a atenção para a natureza construída do abismo supostamente instransponível entre a Europa e a África. ${ }^{24}$

A negação da mistura étnica/racial na antiguidade, em outras palavras, deve ser vista dentro do contexto mais amplo do surgimento do colonialismo e de uma nova epistemologia eurocêntrica que negava o sincretismo cultural $e$ insistia no choque essencialista das civilizações. Embora uma narrativa eurocêntrica construa um muro artificial de separação entre culturas européias e não européias, a própria Europa é uma síntese de muitas culturas, ocidentais e não ocidentais. A noção de uma Europa "pura" originada na Grécia clássica está fundada em exclusões cruciais, das influências africanas e asiáticas que deram forma à própria Grécia clássica, à osmótica cultura sefaradi-

${ }^{23}$ Patrick Buchanan supunha essa separação quando fez sua notória afirmação de que "imigrantes zulus para a Virgínia seriam mais difíceis de assimilar do que imigrantes ingleses". No The New York Times (8 de março de 1992), Stephen L. Carter observou que muitos zulus na África do Sul falam um inglês melhor que os europeus que tanto encantam Buchanan. Em carta posterior ao editor (de 9 de março de 1992), Lorna Hahn afirma que há descendentes de zulus na Virgínia de hoje que não só participam ativamente da vida pública mas "até se tornaram republicanos conservadores". Devemos também questionar a insistência conservadora em invocar os zulus para seus propósitos retóricos, como na observação também notória de Saul Bellow sobre a falta de um "Proust zulu". Seria a palavra "zulu" preferida por suas ressonâncias cômicas para o ouvido ocidental, ou por incluir foneticamente o som "zôo"?

${ }^{24} \mathrm{~A}$ arte ocidental sempre teve dívidas e foi transformada pela arte não ocidental. Especialmente no caso do modernismo, o movimento das idéias estéticas tem sido (pelo menos) nos dois sentidos, donde a influência moura na poesia do amor cortês, a influência africana na pintura modernista, o impacto de formas asiáticas (kabuki, teatro no, teatro balinês, escrita ideográfica) sobre o teatro e o cinema europeus e a influência de formas africanizadas não só no musical de Hollywood, mas também em coreógrafos como Martha Graham e George Balanchine. Ver também NEDERVEEN, Pieterse Jan. Empire and Emancipation: Power and Liberation on a World Scale. Londres, Pluto, 1989. 
judaico-islâmica que desempenhou papel fundamental no período de ascendência oriental, na Idade Média e no Renascimento. Todos os "estágios" célebres do progresso europeu - Grécia, Roma, a Cristandade, o Renascimento, o Iluminismo - são momentos de sincretismo cultural. O "Ocidente", então, é ele mesmo uma herança coletiva, uma mescla onívora de culturas; ele não absorveu simplesmente influências não européias; foi constituído por elas. ${ }^{25}$

$\mathrm{E}$, no entanto, de uma perspectiva eurocêntrica, a Grécia é construída como puramente européia, e, portanto, branca, enquanto que para o afrocentrismo o Egito é africano, e, portanto, por definição, negro. Ambas as lógicas segregacionistas especulares, contudo, ignoram o problema do sincretismo cultural, especialmente dentro do espaço do Mediterrâneo. Mesmo que quiséssemos afirmar a pura brancura ou negritude de Cleópatra, o que diríamos sobre sua cultura? Assim como afirmar a idéia do "sangue puro" em qualquer lugar é uma idéia historicamente suspeita, também o é a de culturas puras. Como a maioria dos mundos culturais, o de Cleópatra era complexo: as porosas fronteiras culturais entre as civilizações da Grécia e do Egito permitiam o choque, o diálogo, o empréstimo e, em última análise, a mútua transformação. A suposição de que trezentos anos de população greco-macedônia no Egito não teriam produzido uma mistura cultural suficiente para fazer de Cleópatra uma figura sincrética é altamente questionável. Alguns escritores, entretanto, afirmaram que, embora Cleópatra falasse egípcio, ela era grega. Mas, mesmo que suas origens fossem de fato "puramente greco-macedônias", tal discurso implica que a coabitação em um lugar por gerações, bem como o domínio de sua língua e cultura nativas, são irrelevantes para formar a identidade; pois a identidade é estritamente definida pelas origens biológicas e geográficas. Assim como no debate da cor de Cleópatra, também aqui os discursos antropológicos do século

${ }^{25}$ ID., IB., p.360. 
Des-orientar Cleópatra

dezenove, ligados apenas às genealogias etno-culturais $e$ ao mapeamento de noções fixas e essencialistas de identidade, têm impacto sobre a configuração da filiação cultural de Cleópatra e, por assim dizer, a petrificam.

O debate sobre a identidade de Cleópatra seria profundamente beneficiado por um discurso mais complexo sobre suas múltiplas filiações culturais. Como sua cidade, Alexandria, pode-se também dizer que Cleópatra pertenceu a pelo menos duas culturas, cada uma delas por sua vez um palimpsesto de culturas diversas. Viagens, comércio, aprendizado, tradução, conquista, ao lado de estupro e casamento, tudo isso resultou em uniões e no amálgama de populações e culturas. A dicotomia oriente contra ocidente, além disso, não pode ser projetada sobre o mundo de Cleópatra ou sobre uma história milenar de mistura cultural. Precisamos transcender a tendência a erigir narrativas totalizantes e essencialistas da cultura para desenhar a identidade de Cleópatra. Uma visão historicizada do Egito e da Grécia, como a que aqui tentamos, situa Cleópatra dentro de uma concepção fluida, dialógica e dinâmica da identidade cultural.

\section{Estética iluminista e cultura visual}

Ao negarem a possibilidade de uma ascendência africana negra a Cleópatra, os debates contemporâneos traem, como vimos, um comprometimento com a brancura dela. Um certo silogismo não expresso parece estar em operação: Cleópatra tinha um visual atraente; visuais atraentes são brancos; logo, Cleópatra deve ter sido branca. O debate sobre a raça de Cleópatra inevitavelmente atinge, nesse sentido, visões rivais de beleza, cada uma delas armada de sua definição normativa. A paixão por uma Cleópatra branca, em minha opinião, pode ser situada na estética iluminista e nos discursos científicos raciais do século dezenove. ${ }^{26}$

${ }^{26}$ Ver também WeST, Cornel. Prophecy Deliverance: an Afro-American Revolutionary Christianity. Louisville-Filadelfia, Westminster Press, 1982 e TAYLOR, Clyde. Black Cinema in the Post-Aesthetic Era. In: PINES, Jim e 
Um racismo de gênero deixou sua marca na estética iluminista repleta de reverências ao ideal da brancura. As mensurações e ordenamentos característicos das novas ciências eram acoplados a juízos estéticos de valor derivados de uma leitura apolínea de uma Grécia não mais dionisíaca. Arianistas como Carl Gustav Carus mediam o divino na humanidade através da semelhança com as estátuas gregas. A religião da arte, por sua vez, também prestava homenagens no altar da brancura, dentro de um olhar normativo que vem sistematicamente desvalorizando toda aparência $e$ estética não européia. ${ }^{27}$ Para Gobineau, "a raça branca tinha originalmente o monopólio da beleza, da inteligência e da força". ${ }^{28}$ Para Buffon, "[A Natureza] em sua atuação mais perfeita fez os homens brancos". ${ }^{29}$ Fredrich Bluembach chamou os europeus brancos de "caucasianos" porque acreditava que as montanhas do Cáucaso eram a terra de origem da espécie humana mais bela. ${ }^{30} \mathrm{Em}$ que lugar senão entre os caucasianos, perguntava retoricamente o cirurgião britânico Charles White, encontrar... "cabeça de nobre curvatura, com tanto cérebro... Em que outra parte do globo encontrar o rubor que se espraia nas suaves feições das belas mulheres da Europa". "Embora as

Williamson, Paul. (orgs.) Questions of Third Cinema. Londres, BFI, 1989; HOOKS, bell. Black Looks: Race and Representation. Boston, South and Press, 1992.

${ }^{27}$ WHITE, Charles. Account of the Regular Gradation in Man apud GoulD, Stephen Jay. The Mismeasure of Man. Nova Iorque, W.W. Norton \& Co., 1981, p.42.

28 apud STREET, Brian V. The Savage in Literature. Londres, Routledge \& K. Paul, 1975, p.99.

${ }^{29}$ BufFON, George-Louis Leclerc de. The History of Man and Quadrupeds. Londres, New Edition, 1812, p.422. (Trad.: William Smellie.)

${ }^{30}$ Mosse, George. Towards the Final Solution: A History of European Racism. Londres, JM Dent \& Sons Ltd., 1978, p.44.

${ }^{31}$ Minha discussão aqui sobre a estética iluminista se baseia em meu trabalho em co-autoria com Robert Stam. SHOHAT, E. e STAM, R. Unthinking Eurocentrism. Op. cit. 
Des-orientar Cleópatra

descrições de White claramente ponham o cérebro do homem acima da beleza das mulheres, em última análise acolhem a mulher que pertence geneticamente à família do homem (branco).

Como resultado do surgimento de conceitos biológicos evolucionistas da raça, e da ciência da ordem e da medida, os traços de Cleópatra foram submetidos a escrutínio. Os apaixonados debates sobre o nariz de Cleópatra, por exemplo, coincidiram com a emergência de configurações raciais da beleza. "Tudo o que a poesia podia fazer", escreve William Maginn, "foi feito, para fazer-nos esquecer as faltas de Cleópatra, e para pensar que um mundo se perdeu por aquela curvatura do nariz" ${ }^{32} \mathrm{~A}$ representação visual de Cleópatra às vezes envolveu uma operação de limpeza, livrando a antiga rainha de traços ditos não europeus, como o nariz adunco, de modo que aproxima a remodelação visual para dar uma aparência ariana a Cristo, considerada mais apropriada ao ser supremo. A novela de Lord Berners, $O$ Romance do Nariz, oferece uma narrativa de redenção do nariz de Cleópatra. ${ }^{33}$ Descreve Cleópatra como a mulher mais bela e elegante do mundo, "mas, oh, com aquele nariz!" Para consertar o monstruoso nariz, ela se submete a uma cirurgia plástica com Apolodoro. Este arranja um desfile de escravas para que ela escolha seu novo nariz, mas ela escolhe como modelo uma representação artística perfeita - uma cópia de um busto de pedra de uma mulher Síria. Ao ver o novo nariz, Cleópatra tira a roupa e começa a dar cambalhotas. Outros escritores, vendo o grande nariz de Cleópatra como uma desfiguração, tentaram redimir seus traços com descrições mais fortes de sua grandeza. Anatole France escreveu que as medalhas em que Cleópatra aparece

\footnotetext{
${ }^{2}$ MaginN, William e Mackenzie, Shelton R. Lady Macbeth. The Shakespeare Papers of the Late William Maginn. Nova Ioque, Redfield, 1856, p.184.

${ }^{33}$ BERnERS, Lord. The Romance of a Nose. Londres, Constable, 1941.
} 
todas a representam com traços grandes e grosseiros, e um nariz excessivamente longo... se formos acreditar nas medalhas, esse nariz era inteiramente desproporcional; mas não acreditaremos nelas; nem que coloquem à nossa frente todas as coleções de medalhas da Biblioteca Nacional, do Museu Britânico, e do Gabinete de Viena... Os traços que levaram César a esquecer o império do mundo não foram prejudicados por um ridículo nariz. ${ }^{34}$

Nem todas as culturas consideraram feio o nariz adunco. Diferentes épocas e diferentes espaços geo-culturais possuíram diversas normas estéticas, inseparáveis de ideologias do corpo e da sexualidade fundadas no gênero. A relatividade da beleza já estava avançada na antiguidade, implícita na sugestão de Sextus Empiricus de que os etíopes preferiam as mais negras e de nariz mais achatado $e$ os persas as mais brancas e de nariz mais adunco. ${ }^{35}$ Escritores contemporâneos, mesmo quando fazem o gesto para a dificuldade de definir a beleza, expressam fortes convicções sobre a beleza ou a feiúra de Cleópatra. As únicas representações realmente confiáveis de Cleópatra, segundo Lucy Hughes-Hallett, são as preservadas em moedas, inclusive as moedas do molde da própria Cleópatra. Embora essas moedas pretendessem lisonjeá-la, ainda assim a mostravam "com um enorme nariz adunco, e uma espécie de queixo de bruxa curvo em direção do nariz, e que não pode de nenhuma maneira ser descrito como atraente por nenhum padrão". ${ }^{36}$ Evocando a possibilidade de múltiplos padrões estéticos, Lucy HughesHallett aceita o relativismo, mas no mesmo passo endossa normas de beleza informadas pela tradição greco-romana-ariana, especificamente a idéia do nariz reto ou voltado para cima como modelo de beleza. Bruxas, não nos esqueçamos, eram retratadas

${ }^{34}$ FranCE, Anatole. Prefácio a Cleopatra, de Téophile Gautier, Paris, 1899.

${ }^{35}$ SNOWDEN JR, F. M. Blacks in Antiquity... Op. cit., pp.7 e 178.

${ }^{36}$ Hughes-Hallett, Lucy. Cleopatra: History, Dreams and Distortions, Londres, 1990, 1997; Intimate Portrait-Cleopatra, Race and Beauty. Lifetime TV, 1997. 
Des-orientar Cleópatra

com os mesmos traços "repelentes" - o nariz adunco que se encontra com o queixo curvado para cima - que os judeus dentro do discurso mitológico com inflexões tanto de anti-semitismo quanto de sexismo. Se Cleópatra de fato tinha um nariz adunco, um queixo voltado para cima, ou pele escura, nós certamente não o saberíamos a partir da cultura dos meios de comunicação de massa que vem espalhando globalmente imagens eurocêntricas de beleza, a ponto de que mesmo o reconhecimento da relatividade da beleza ainda afirma uma perspectiva implicitamente hegemônica. A questão, portanto, não é simplesmente se Cleópatra era ou não considerada bela em sua época, mas como essas discussões da aparência marcadas pelo gênero e pela raça são emblemáticas da cultura visual eurocêntrica.

Desde seu começo, o cinema foi obcecado com antigas civilizações. Ele mesmo produto das descobertas científicas ocidentais, o cinema tornou palpável para o público a grande narrativa do progresso da civilização ocidental, muitas vezes através de narrativas biográficas sobre exploradores, inventores $e$ cientistas. Como produto auto-articulado do engenho científico, o cinema via a si mesmo como manifestação de um novo tipo de ciência interdisciplinar que podia tornar acessíveis "outros" mundos. Desenharia um mapa do mundo como o cartógrafo; narraria os eventos como o historiador; escavaria o passado remoto como o arqueólogo; e faria a anatomia dos costumes de povos exóticos como o antropólogo. Em seu papel de pedagogo, o cinema dominante prometia iniciar o espectador ocidental em culturas desconhecidas, visualizadas e vividas (ao modo de Hegel) "fora da história". O cinema tornava-se assim o mediador epistemológico entre o espaço cultural do espectador ocidental e o das culturas representadas na tela, ligando espaços separados e temporalidades separadas num único momento de exposição.

Nesse sentido, o cinema encenou um papel historiográfico e antropológico, escrevendo (em luz) a cultura dos "outros". A queda dos filmes mudos por significantes grafológicos como 
hieróglifos (nas diversas versões de Cleópatra), símbolos hebreus (Intolerância) ou as páginas de um livro aberto (como no "Livro da Intolerância", em conjunto com as "notas" didáticas que acompanham os intertítulos) apontam para o papel de Hollywood como arquivista e historiadora. Associando-se à escrita, e em particular à escrita "original", o cinema emprestou uma aura artística e histórica grandiosa a um meio ainda associado aos espetáculos circenses. Ligando uma arte nova, aprendiz, a tempos antigos e lugares remotos, reivindicava poderes quase arqueológicos, ressuscitando civilizações esquecidas tanto na tela quanto arquitetonicamente nas salas de cinema pseudo-egípcias. Feitos num período em que os povos colonizados começavam a afirmar uma contra-identidade em relação a seus colonizadores, esses filmes suprimem conflitos contemporâneos em favor de uma busca nostálgica e romântica pelas perdidas origens orientais do ocidente. Só esse traço contextual explica uma ausência estruturante nas representações hollywoodianas do Egito, da Babilônia e da Terra Santa (Bíblica): a ausência de retratos do oriente árabe contemporâneo, colonizado, e de suas lutas nacionalistas. Os filmes definem o oriente como antigo $e$ misterioso, descrito por uma iconografia de papiros, esfinges $e$ múmias, cuja existência e sobrevivência dependem do "olhar" e "leitura" do ocidental. Em outras palavras, o resgate putativo do passado suprime o presente e, assim, legitima a disponibilidade do espaço oriental para manobras geopolíticas ocidentais. A zona fílmica mumificada das civilizações antigas, em suma, participou ativamente da geração de uma época imperial.

O cinema como meio visual não tinha como deixar de se envolver com a cor da pele de Cleópatra e com seus traços. Diferentemente dos romances, a aparência e a descrição no cinema são fundados no concreto e no específico; frases como "belo rosto" e "olhos sedutores" têm que ser traduzidos na forma, cor e traços de um ator ou atriz particular. A adaptação visual de narrativas orais e escritas, mesmo quando se trata de figuras históricas, força o pintor e o fotógrafo a tomar, por 
Des-orientar Cleópatra

assim dizer, uma posição. A natureza do cinema requer a seleção de atores e atrizes, e um processo de atribuição de personagens que inevitavelmente situa face e corpo em conceitos de raça. $\mathrm{Na}$ tradição da cultura popular ocidental, o cinema deu prosseguimento à iconografia de uma Cleópatra branca. Dada a ideologia das estrelas, a política de seleção de personagens de Hollywood não podia ter uma Cleópatra não branca. A grandiosidade de uma figura histórica "maior do que a vida" tinha que ser refletida alegoricamente por uma estrela "maior do que a vida", posição que, até recentemente, excluía mulheres não brancas. Nem uma rainha venerada, nem uma estrela adorada poderiam ser visualizadas e imaginadas como não brancas, o que as tornaria "menores que a vida". O espaço segregado da tela também impunha um tabu sobre romances mistos. O Código de produção dos Produtores e Diretores de Filmes da América (1930-34) afirma explicitamente: "A miscigenação (relações sexuais entre as raças branca e negra) é proibida". O código refletia leis segregacionistas que supunham as categorias fictícias sangues "branco" e "negro", e que definiam a miscigenação como "crime de sangue". A interação (hetero) sexual erótica antes do fim da década de 60 era severamente limitada por códigos raciais ao estilo do apartheid. A deslegitimação de uma união romântica entre "brancos" e outras "raças" estava ligada a uma ampla prática social excludente em que a definição biológica da raça estava embebida do conceito político de raça e da hierarquia de civilizações marcadas pelo gênero.

Herdada do discurso colonialista, a estética hegemônica do "branco é belo" foi vista em romances de aventura sem conta, para não mencionar filmes como Trader Horn (1930) e King Kong (1933) que mostram "nativos" em nua adoração do fetiche da beleza branca. A ideologia da escolha de papéis de Hollywood se conformava ao ideal estético ariano. Se a Cleópatra histórica de fato tivesse tais traços "negativos", as normas de beleza de Hollywood não teriam permitido que a imagem da rainha/estrela fosse "denegrida". Na lógica de faz de conta de Hollywood, a 
superioridade moral e o espírito triunfante do herói ou da heroína são traduzidas numa suposta superioridade visual. No contexto das narrativas imperiais, os traços físicos de Cleópatra provocam inevitavelmente um debate sobre a representação visual. A idéia de que Cleópatra não era negra significa que ela era parecida com as atrizes Theda Bara, Claudette Colbert, Vivian Leigh, ou Elizabeth Taylor, que desempenharam seu papel? Mesmo que aceitemos que ela era grega, e, portanto, sua suposta brancura de que modo representar a brancura? Essas atrizes encarnam antigas noções de beleza grega, egípcia ou romana? A escolha de papéis dentro do sistema de astros e estrelas claramente envolvia normas estéticas que louvavam uma visão específica de beleza. $\mathrm{Na}$ era do cinema mudo, atrizes de pele pálida como Lílian Gish e Mary Pickford eram versões icônicas da virgem branca, surgindo em relação diacrítica com a imagem do repulsivo selvagem negro. A idealizada pálida heroína também surgia em contraste com a vamp mais escura, associada a atrizes como Theda Bara, Nita Naldi, Alla Nazimova, em geral, "brancas" mais escuras. Caracterizadas por cosméticos pesados, com olhos e lábios perigosamente sedutores e virtualmente vampíricos, sua aparência dava um toque de escuro no domínio da erótica intra-branca.

A representação da negritude como desejável, porém, continuou tabu - além do pálido, por assim dizer, um "deslizamento" para além dos limites do exótico. Ainda que ausentes dos refletores, enquanto "produtoras" do desejo, as mulheres de cor estavam presentes enquanto consumidoras do desejo. Desde o fim do século dezenove, a indústria de cosméticos tinha a comunidade afro-americana como alvo, a fim de ampliar mercado. ${ }^{37}$ Desenvolvendo estratégias de propaganda específicas para vender cosméticos para mulheres negras, os anúncios utilizavam imagens de refinamento e mobilidade social ligadas à

\footnotetext{
${ }^{37}$ PEISS, Kathy Lee. Making Faces: The Cosmetics Industry and the Cultural
} Construction of Gender, 1890-1930. Genders 7, 1990, pp.158-159. 
Des-orientar Cleópatra

cor branca. ${ }^{38}$ Anúncios de clareadores de pele, por exemplo, alimentavam a fantasia da mudança e da libertação dos grilhões da história e da cor negra. Os anúncios dirigidos às mulheres brancas de classe média, enquanto isso, evocavam o "exótico" um espaço imaginário de alteridade, de geografias sedutoramente misteriosas, de viagens, aventura e exploração. Para mulheres em sua maioria confinadas em suas casas, o exotismo ajudava a construir a imagem de uma mulher aristocrática, cujos horizontes se ampliavam com seu livre movimento no mundo dos poderes imperiais em expansão. ${ }^{39}$ Anúncios de cosméticos punham no mercado certas identidades exóticas alternativas - Oriental, Ilhas do Pacífico -, retendo ao mesmo tempo um núcleo de normatividade branca. No início dos anos 1930, por exemplo, Hollywood e Max Factor desenvolveram linhas exóticas de cosméticos que exibiam suas estrelas de cabelos escuros, como Hedy Lamarr, Dolores del Rio, Dorothy Lamour e Rita Hayworth, em lugar da aparência branca monocromática das loiras platinadas. ${ }^{40} \mathrm{O}$ gesto em direção de outras possíveis normas de beleza mercantilizou a diferença, mas só até certo ponto. Produzida para atrair mulheres de diversas etnias, a imagem de Cleópatra era só um pouco mais escura que a pálida imagem feminina média que ilustrava muitos anúncios; mas nunca muito escura, e certamente nunca traindo traços "não brancos", por exemplo, um nariz adunco ou achatado. Os simulacros étnicos de

\footnotetext{
${ }^{38} \mathrm{~A}$ imagem de Cleópatra foi usada em vários anúncios, e a esta altura já entrou no cyberespaço como, por exemplo, "A estória do segredo de Cleópatra" - sítio criado por uma egípcia para vender um produto de remoção de pelos.

${ }^{39}$ Durante a última década apareceram inúmeros livros sobre mulheres viajantes. Para discussão e bibliografia, ver SHOHAT, E. e STAM, R. Unthinking Eurocentrism. Op. cit.; KAPLAN, Caren. Questions of Travel; Postmodern Discourses of Displacement. Durham, N. C., Duke University Press, 1996; GREWAL, Inderpal. Home and Harem: Nation, Gender, Empire, and the Cultures of Travel. Durham, N.C., Duke University Press, 1996.

${ }^{40}$ BerRY, Sarah. Screen Style: Consumer Fashion and Femininity in 1930s Hollywood. Minneapolis, University of Minnesota Press, 2000, p.95.
} 
Hollywood fabricavam um espetáculo de diferença enquanto escondiam diversos "outros" na narrativa. Como na seleção de modelos pela indústria de cosméticos, a política de escolha de papéis de Hollywood submergia eficazmente o multiculturalismo no centro da formação nacional norte-americana, oferecendo em lugar dela uma hierarquia racial visualmente codificada.

O debate sobre a aparência de Cleópatra, então, sugere as intensas relações entre raça, gênero e sexualidade. Afinal, discursos da antiguidade não tentaram dissecar da mesma forma imagens de fragmentos corporais de César ou de Antonio. Nem o conceito de "beleza fatal" se estende igualmente à masculinidade. Em anos recentes, escritoras têm insistido nas realizações de Cleópatra como intelectual e como líder abençoada por grande gama de talentos, inclusive o de falar muitas línguas sem precisar de intérprete. Assim, Lucy Hughes-Hallett sublinha a capacidade intelectual de Cleópatra, criticando a ênfase equivocada na aparência da rainha. Leituras feministas de Cleópatra emergem contra o pano de fundo do olhar fetichista focado principalmente na sua beleza erotizada. Em inúmeras representações, o corpo de Cleópatra serviu como metáfora de um Egito feminizado. Em Cleópatra (1934) de Cecil B. de Mille, César se dirige a Cleópatra ordenando: "Egito, sente-se!" E perto do fim do filme, quando Antonio cai sobre a espada, acreditando que Cleópatra o traiu, murmura: "Estou morrendo, Egito, estou morrendo". A câmera enfoca seu corpo como seus homens romanos se dirigem a ela, ou quando ela se prepara para a morte. Vestida de preto, com um decote baixo, ela se senta no trono e tira de uma cesta uma áspide de 30 centímetros, aplicando-a ao seio. Independente do fato histórico sobre o réptil e onde ele foi aplicado, imaginar uma cobra no seio de Cleópatra parece estimular uma representação falocêntrica da história - do triunfo do Império Romano masculinizado. Em tal representação, o poder de Cleópatra - e o poder do Egito - está em sua sexualidade; com sua morte, morre um mundo inteiro. 
Des-orientar Cleópatra

Representações européias de civilizações antigas feitas no século dezenove, estimuladas por descobertas arqueológicas, também exibem figuras de gênero para projetar o presente imperial nos encontros passados entre o ocidente e o oriente. $\mathrm{E} o$ retrato romântico do antigo oriente de Babilônia e Egito, reproduzido em filmes como Intolerância (1916) de D. W. Griffith e Cleópatra (1934) de Cecil B. de Mille, projetam o oriente como feminino. Em Intolerância, a Babilônia significa excesso sexual, com base na descrição da cidade no Livro da Revelação como "a Mãe das Prostitutas e das Abominações da Terra". Na Cleópatra de de Mille, os compatriotas de César lhe dizem: "A mulher está fazendo de você um egípcio" e Brutus insiste em que "Roma não pode se tornar um outro oriente" - tudo dentro da moldura que associa Roma à masculinidade e o Egito à feminilidade. A arquitetura monumental, o detalhe doméstico, as festas semipornográficas nesses filmes refletem uma obsessão com a abundância material do antigo oriente, obsessão compartilhada pela literatura colonial de viagens, que também detalhava obsessivamente os excessos sensuais orientais. A submissão de Cleópatra e do Egito nos filmes tem ressonâncias coloniais contemporâneas: a corte romana parece ser composta de aristocratas ingleses que fazem piadas sarcásticas sobre a idéia de que uma Cleópatra supostamente negra possa governar Roma. $\mathrm{E}$ isso a despeito do fato de que as convenções estéticas de Hollywood, como já dissemos, visualizam Cleópatra como uma mulher de aparência européia, da mesma maneira como Cristo foi gradativamente des-semitizado na iconografia ocidental.

Escalar uma atriz forte para o papel de Cleópatra produz tensões entre ideologias de gênero e raciais. A Cleópatra de Mankiewicz parece dotar a antiga rainha e a atriz contemporânea com o poder do olhar. De trás de uma parede, Cleópatra (Elizabeth Taylor) espia uma conversa em que César discute a rainha que acabou de conhecer, tornando o espectador consciente do que César não sabe. Dentro dessa estruturação cinematográfica de uma brecha no conhecimento entre o 
personagem e o espectador, este último se liga ao ponto de vista de Cleópatra. Seu olho espia pelo pequeno buraco na parede, invisível por trás do mural do desenho egípcio de uma face de mulher maior do que a vida. Feito para lembrar antigas pinturas egípcias, o olho de Taylor olha através do olho da figura no mural, dando "tridimensionalidade" à pintura bidimensional, numa passagem que aproxima o olho de Taylor e o olho da figura mural, na forma e na cor, fazendo uso da famosa cor violeta dos olhos da atriz. Quando o espectador olha o olho mais azul/mais violeta, misturando uma branca estrela contemporânea com uma antiga rainha egípcia - o diálogo de César nos informa de suas origens macedônias, e de que ela "não tem uma gota de sangue egípcio". Nesse momento de uma visualização semi-ariana de Cleópatra, seu caráter ganha um poder provisório do olhar, do tipo em geral associado à masculinidade. De maneira ainda mais típica, porém, os filmes de Hollywood autorizam um olhar voyeurista masculino sobre um espaço privado inacessível. Em filmes como Kismet (1955) o objeto tipo panopticon permite ao chefe do harém espiar suas muitas mulheres sem que elas saibam. Dotar Taylor/Cleópatra da capacidade de vigiar se afasta da fantasia que cerca os haréns de Hollywood, que são utopias masculinas heterossexuais de onipotência sexual. E, no entanto, o momentâneo poder de olhar de Cleópatra lhe é retirado quando ela não é mais a delegada da brancura suprema, e ela é induzida, por assim dizer, a assumir a posição da estrela, isto é, ser olhada. Em todo o filme Cleópatra, o corpo da rainha/estrela é sujeito a voyeurismo do espectador, como na cena em que Taylor/Cleópatra tira a roupa e se entrega ao prazer do banho, a água azul chegando-lhe ligeiramente acima dos seios. Três décadas depois essa imagem de Taylor como Cleópatra no banho foi invocada num anúncio do próprio perfume de Taylor, "Passion". O corpo de Taylor, como o de Cleópatra, torna-se um lugar ambivalente, ao mesmo tempo poderoso pela economia de sua (branca) sexualidade e sem poder pela cultura da vigilância de que é objeto. 
Des-orientar Cleópatra

É só contra o pano de fundo dessa longa história de glorificação da brancura e de desvalorização da negritude que se pode apreciar a força emocional da contra-expressão "Negro é belo" (Black is Beautiful) e o desafio provocador da própria noção de uma Cleópatra negra. As normas da estética eurocêntrica exilaram as mulheres de cor de seus próprios corpos. Até o fim dos anos 1960, a grande maioria das revistas de modas, filmes, programas de TV e comerciais anglo-americanos promoveram uma noção canônica de beleza dentro da qual as mulheres brancas (e secundariamente os homens brancos) constituíam os únicos objetos legítimos do desejo. Ao assim fazerem, os meios de comunicação estenderam uma já duradoura valorização filosófica da brancura. Num século em que a cultura popular atingiu um grau sem precedentes de massificação, a representação de Cleópatra tem que ser discutida não só em termos dos esforços históricos para reconstruir como ela era realmente, mas também em termos do poder real de produzir e projetar sua imagem sobre o mundo do consumo. Tais representações, como tentei sugerir, têm repercussões e reverberações reais no mundo $e$ aqui, também, devemos ver Cleópatra não só como uma figura da antiguidade, mas também como um tropo da modernidade.

Alegorias de nação e diáspora

Reivindicar uma raça e uma nação específicas para Cleópatra é sempre um ato relacional que se opõe a reivindicações alternativas. A articulação de identidade nacional se apóia pesadamente numa linguagem simbólica de origem $e$ filiação, mas sua escrita do passado muitas vezes se confrontou com outras escritas. A própria maneira como a questão da identidade de Cleópatra é posta revela a profundidade de um pensamento estrutural binário: era negra ou branca, africana ou européia, grega ou egípcia, macedônia ou grega. As emoções expressas a favor de qualquer uma única identidade de Cleópatra demarcam uma particular fronteira territorial e/ou 
cultural. Representações contemporâneas de Cleópatra, em minha opinião, são assombradas por essas dicotomias, que podem ser entendidas como ao mesmo tempo impondo práticas hegemônicas excludentes e resistindo a elas. As disputas sobre Cleópatra podem ser lidas, nesse sentido, como alegorias que reinventam identidades nacionais e de diáspora e seu lugar no mapa global.

Durante os anos em que foram produzidos os principais filmes sobre Cleópatra, os discursos raciais norte-americanos só permitiam negros em papéis subordinados. No mesmo ano em que Claudete Colbert fez o papel de Cleópatra, ela também atuou como a maternal rainha do lar em Imitação da Vida, servida por uma empregada negra, tipo Aunt Jemima, cuja filha, Piola, passa por branca. Na Cleópatra dos anos 1960, entretanto, os negros eram mais visíveis nas extravagantes seqüências de danças $e$ trabalhando como serventes ou escravos - como se o antigo Egito também fosse organizado em torno das modernas hierarquias raciais típicas do Atlântico negro colonial. Foi só na década de 1970, quando a cultura popular apropriou e deu voz a ícones do Poder Negro (Black Power) e símbolos afrocêntricos, que uma Cleópatra negra chegou à tela. Sua representação, porém, foi adaptada ao tom paródico do gênero blaxploitation, em geral domínio da masculinidade negra (hétero), no caso, recebendo uma rainha negra contemporânea. No filme Cleopatra Jones e na seqüencia Cleopatra Jones and the Casino of Gold, a supermodelo Tamara Dobson é a estrela como uma agente da CIA que enfrenta traficantes de drogas e o submundo. Enquanto a maioria dos filmes do gênero se ocupam da bravura dos negros, aqui a agente especial Cleopatra Jones derrota impérios do mal com seu kung fu, chutando alto e pensando rápido. Esses filmes invertem a codificação hollywoodiana da cor, brincando com a tendência de associar personagens brancos com o bem e personagens negros com o mal. Atrizes brancas são escaladas para os papéis das adversárias que chefiam cartéis criminosos, como Shelley Winters como a lésbica vestida de couro preto em Cleopatra Jones, ou 
Des-orientar Cleópatra

Stella Stevens como a loura apelidada de "branca de neve" em Cleopatra Jones and the Casino of Gold. Algumas seqüencias de Cleopatra Jones, de maneira bem humorada, aludem à superprodução de Mankiewicz dez anos antes, como quando Cleópatra, com o penteado e cosméticos similares aos de Elizabeth Taylor, pisca para crianças negras na rua, numa alusão à seqüência da apresentação de Cleópatra a Roma que termina com Cleópatra/Taylor piscando para César (e para o espectador). Cleopatra Jones and the Casino of Gold, por sua vez, faz com que a heroína negra mate a vilã loura em seu próprio banho/piscina, uma referência à famosa tomada do banho de Taylor no filme de Mankiewicz. Enquanto que a seqüência da superprodução dos anos 1960 fora projetada como um monumento à beleza e sensualidade de Taylor/Cleópatra, a seqüência do banho de Dobson encena o adeus do poder branco e, em última análise, goza o investimento libidinal do espectador nas normas eurocêntricas de beleza. Os filmes de Cleopatra Jones oferecem uma subversão lúdica da fábrica racializada de sonhos de Hollywood, de sua brancura mitologizante, que opera através da glamourização de estrelas brancas em geral $e$ mais especificamente pela brancura totêmica de Cleópatra. ${ }^{41} \mathrm{~A}$ heroína afro-americana é visualmente associada a signos do movimento "Black Power" - cabelo afro, punho fechado, roupas afro. Escalar a alta Tamara Dobson, com seu cabelo afro, cuja presença visual evoca as famosas imagens da revolucionária negra Angela Davis, contribui para essa sensação de desmistificação paródica tanto da rainha branca quanto da estrela branca. Dentro do nacionalismo do filme, porém, "Angela Davis", mansa e domesticada, é reconstruída para corresponder à ordem social existente; pois ela trabalha para a CIA, encarnada pelo último patriarca branco, seu chefe. É ele que permite que a forte e sexy Cleopatra Jones

${ }^{41}$ Recentemente, o filme paródia de Jay Roach, Goldmember (2002), homenageia a cultura popular dos anos 1970, inclusive os filmes de blaxploitation. Ao herói do filme, Austin Powers (Mike Myers) junta-se a heroína Foxy Cleopatra (Beyonce Knowles) para enfrentar o Dr. Mal e seu clone. 
resgate seu próprio "Egito" - a comunidade negra. Conflitos raciais e rebelião negra são apropriados como uma saga familiar norte-americana.

Cleópatra tem sido reivindicada não só por nacionalistas negros na diáspora, mas também por diversos outros movimentos nacionalistas. ${ }^{42}$ A Grécia e a Macedônia têm disputado Alexandre o Grande, cujo antigo reino no século IV a.C. se expandia além dos Bálcãs, pela Ásia e pela África, e que, simbolicamente, incorpora um glorioso passado nacional. O debate sobre uma Cleópatra puramente macedônia ou grega - descendente de Alexandre - faz parte dos Bálcãs de hoje, região dividida por conflitos étnicos e nacionais. A luta dos Bálcãs pela identidade étnica e nacional está mergulhada em diversas lógicas excludentes. Uma certa dicotomia oriente versus ocidente torna a cristandade equivalente à Europa e ao ocidente, deixando os muçulmanos dos Bálcãs como orientais "fora" da identidade européia. A fundação de um estado-nação macedônio tem como premissa a consolidação de uma identidade separada em relação à Grécia. A figura de Alexandre o Grande constitui uma genealogia definidora para a nação macedônia investida ao invocar antigas origens civilizacionais anteriores à dominação otomana da região. Os traços indesejados dessa história, dentro desta perspectiva, ainda marcam os Bálcãs, traços tornados "visíveis" em sua população muçulmana "estrangeira". Finalmente, nesta perspectiva exclusivista, as triunfantes realizações da cultura ocidental se originam da antiga Grécia, na qual a Macedônia desempenhou papel central. $O$ desejo balcânico de uma identidade "ocidental" é dependente da reinvenção iluminista da Grécia como um espaço europeu puro, sem elementos africanos, semitas, fenícios e outros elementos "orientais". A integração com a Europa Ocidental permite à

${ }^{42}$ Em Israel, Roni Somech, poeta e compositor iraquiano, também escreveu um poema sobre Cleópatra. E o compositor e cantor Yair Dalal deu expressão a outra existência na diáspora em que a cultura árabe foi negada a judeus-árabes pela Euro-Israel. 
Des-orientar Cleópatra

imaginação balcânica desorientalizar-se. A antiga presença macedônia/grega no Egito, de modo semelhante, é lida como uma história puramente "Européia". A vida de Cleópatra no Egito, portanto, é meramente uma nota de pé de página, pois ela é vista como pura macedônia ou pura grega, logo, européia. A linhagem de Alexandre-Cleópatra no Egito codifica um imaginário nacionalista em que os Bálcãs se livram das amarras do passado "oriental" ocidentalizando-se. ${ }^{43}$ Assim, embora um milênio separe as figuras de Alexandre e Cleópatra $e$ o domínio muçulmano otomano dos Bálcãs, a leitura da complexa rede cultural mediterrânea, e especificamente a da antiga Grécia/Egito, continua aprisionada em modernos conflitos nacionalistas.

Embora a terra do Egito tenha tido outras rainhas poderosas, a especial paixão reservada a Cleópatra pode ser situada parcialmente na interseção entre o que veio a ser visto como oriente (Egito) e o que veio a ser visto como ocidente (Roma). Mas a adoração a Cleópatra como figura de culto da cultura popular ocidental dificilmente pode ser considerada universal, nem mesmo no Egito, sua terra natal. Em 1933, o ano em que Cecil B. de Mille criou sua representação eurocêntrica de Cleópatra e do choque entre Egito e Roma, o conhecido escritor egípcio Taha Husayn articulou um entendimento mais complexo do encontro das civilizações:

Três elementos formaram o espírito literário do Egito desde que ele se tornou árabe. $\mathrm{O}$ primeiro deles é o elemento puramente egípcio que herdamos do antigo Egito... O segundo... é o elemento árabe, que nos veio através de sua língua e religião e civilização... é nossa língua, e mil vezes mais próxima de nós do que a língua dos antigos egípcios... o terceiro elemento... é o elemento estrangeiro que sempre influenciou a vida egípcia, e sempre o fará. É o que resultou

\footnotetext{
${ }^{43}$ Para uma discussão sobre a auto-ocidentalização dos Bálcãs, ver BJELIC, Busan I. (org.) Balkan as Metaphor: Between Globalization and Fragmentation. Cambridge, Mass., MIT Press.
} 
para o Egito de seus contatos com os povos civilizados a leste e oeste... gregos e romanos, judeus e fenícios nos tempos antigos, árabes, turcos e cruzados na Idade Média, Europa e América na idade moderna... Gostaria que a educação egípcia se baseasse firmemente numa certa harmonia entre esses três elementos. ${ }^{44}$

Alguns intelectuais egípcios, associados à ascensão da modernidade e do nacionalismo, tentaram dar uma visão relativamente sincrética da identidade egípcia. Ainda que, alinhados ao pensamento nacionalista, supusessem um "núcleo" egípcio versus elementos "estrangeiros", esses escritores não formularam um binarismo simplista de cultura egípcia versus cultura grega, fugindo de noções puristas de civilização, cultura $e$ história. Desde o final do século dezenove, a moderna literatura árabe misturava velhos e novos gêneros e formas, dentro de um projeto cultural que mesclava modernidade e nacionalismo. $\mathrm{O}$ surgimento de uma nova poesia e literatura deu expressão a uma nova consciência árabe dentro do mundo moderno. Intelectuais e escritores como Ahmad Shawqi e Taha Husayn tentavam ao mesmo tempo resistir ao colonialismo e formar um nacionalismo de maneira parcialmente inspirada nos contemporâneos discursos britânicos e franceses da modernidade. Nesse contexto, o antigo Egito correspondia ao romantismo dos discursos nacionalistas envolvidos na busca teleológica das origens e genealogias. Também, como os movimentos nacionalistas árabes, como sugere Albert Hourani, se revoltaram contra o presente e também contra o passado imediato, eram capazes de fazer apelo à memória de um passado pré-islâmico mais distante. ${ }^{45}$ Além disso, escavações arqueológicas traziam evidência visível das múltiplas camadas de história que podiam agora ser reivindicadas não só por

${ }^{44}$ Hourani, Albert. A History of the Arab Peoples. Cambridge, Mass., Harvard University Press, 1991, pp.341-42. [Uma História dos Povos Árabes. São Paulo, Cia. das Letras, 1994.]

${ }^{45}$ ID., IB., pp.342-43. 
Des-orientar Cleópatra

egiptólogos europeus, mas também por intelectuais egípcios, cujo nacionalismo, é preciso acrescentar, não estava distante de uma visão iluminista de progresso.

$\mathrm{Na}$ era do colonialismo e neo-colonialismo intelectuais árabe-egípcios abraçavam um antigo Egito que os egiptólogos freqüentemente separavam do Egito contemporâneo, como se os egípcios contemporâneos apenas vivessem no topo de uma grande civilização. Narrativas de resgate arqueológico do antigo Egito tinham o efeito colateral de celebrar a posse de um espaço colonizado. A própria câmera, entretanto, desempenhava importante papel em mostrar ao mundo as civilizações desenterradas, imbuindo cada olhar com o frescor escancarado da nova máquina. E, no entanto, os pioneiros da nova ciência e da imagem gravada raramente questionavam a constelação de relações de poder que lhes permitiam representar outras terras e culturas. Ninguém questionou se e como a terra, a história e a cultura egípcias deviam ser representadas, por exemplo, nem perguntou o que o povo egípcio teria a dizer sobre o problema. Fotógrafos como George Bridges, Louis de Clercq, Maxime du Camp e cineastas como Thomas Edison e os irmãos Lumière não só documentaram outros territórios; também documentaram a bagagem cultural que carregavam consigo. Suas interpretações subjetivas estavam profundamente mergulhadas nos discursos de seus respectivos impérios europeus. Fotógrafos viajantes não mapeavam apenas territórios para usos militares $e$ governamentais; suas fotos também registravam avanços de atividades científicas, especialmente escavações arqueológicas. $\mathrm{O}$ fascínio com os documentos antigos se misturava à admiração com a capacidade de a câmera dar uma vívida imagem de regiões distantes e tempos remotos: uma foto no álbum Egypte, Nubie, Palestine et Syrie (1852) - "o Colosso Ocidental do Templo de Re, Abu Simbel, 1850" - mostra o assistente do fotógrafo sobre a coroa de Ramses II, ilustrando tanto a escala relativa quanto um momento de domínio e posse. 
Para o nacionalismo egípcio, entretanto, a desenterramento do antigo Egito provocou uma sensação de orgulho misturado com um sentimento anti-colonial. Centrais na articulação do nacionalismo egípcio, alguns escritores se inspiravam na descoberta de antigos mundos egípcios, como a do túmulo de Tutankhamon em 1922. Ahmad Shawqi procurou mostrar a continuidade da vida egípcia desde a época dos Faraós até o presente. Em um de seus poemas, escrito para o descerramento de um monumento num parque público no Cairo, Shawqi evoca o olhar inalterado da Esfinge sobre a história egípcia:

Fala! E talvez tua fala nos conduza... Não viste o Faraó em seu poder, dizendo-se descendente do sol e da lua, dando sombra à civilização de nossos ancestrais... Viste César em sua tirania sobre nós, fazendo-nos escravos, seus homens conduzindo-nos à frente como se conduzem burros, e então derrotados por um pequeno bando de nobres conquistadores... ${ }^{46}$

Ainda que desde o final do século dezenove os modernos escritores árabes tenham sido influenciados pela poesia romântica inglesa e francesa, sua "leitura" do antigo Egito era diferente da dos românticos europeus. Se o poema Ozymandias, de Percy Bysshe Shelley fala de um vestígio de perdida grandeza onipotente como metáfora do destino humano e da sensibilidade do poeta, os escritores egípcios desenterraram as pedras do antigo Egito como testemunho vivo da ascensão contemporânea da nação egípcia. Assim, mesmo parte da romantização de Cleópatra na cultura popular egípcia do século vinte não pode ser entendida como derivando meramente de uma história egípcia isolada, mas também da relação do Egito com a Europa - seja através de empréstimos ideológicos seja através da oposição dialética à hegemonia francesa e britânica.

${ }^{46}$ ID., IB., p.342. 
Des-orientar Cleópatra

Com a incursão do imperialismo britânico e francês no Egito, Cleópatra recebeu um significado alegórico ainda mais denso. Cleópatra não entrou na cultura popular egípcia do século vinte meramente como uma antiga rainha egípcia, mas também como uma figura simbólica egípcia para uma nova luta antiimperialista. Na peça Masra'Kilupatra (A Morte de Cleópatra, 1929) de Ahmad Shawqi, Cleópatra está longe do papel de vamp do cinema mudo desempenhado uma década antes por Theda Bara; ao contrário, é uma heroína nacional defendendo seu país contra a agressão imperial européia. Reescrevendo a peça de Shakespeare, Shawqi faz de sua Cleópatra uma estrategista militar cuja fuga de Actium pretende levar as duas forças romanas a uma batalha da qual o Egito emergirá triunfante com o Mar Mediterrâneo à sua disposição. Mais recentemente, Wole Soyinka sugeriu que a peça de Shakespeare já demonstrara o patriotismo egípcio e, portanto, não precisava ser reescrita. ${ }^{47} \mathrm{~A}$ literatura árabe tem mostrado especial fascínio com Shakespeare, especulando que Shakespeare pode em realidade ter sido um árabe, Shyk al Subair - dada sua vívida percepção dos tons, cheiros, gostos e texturas alheios à fria Europa e também sua informada invocação do Livro dos Mortos em cenas que retratam a reflexão de Cleópatra sobre a morte. ${ }^{48}$ Escrita num contexto anti-colonial, a peça de Shawqi dava maior ênfase à resistência a Roma, fazendo uma alegoria à luta dos egípcios pela independência nacional. Ao mesmo tempo, a peça teatral não ignorava o romance entre

${ }^{47}$ SOYINKA, Wole. Shakespeare and the Living Dramatist. In: Art, Dialogue and Outrage: Essays on Literature and Culture. N. Iorque, Pantheon Books, 1993, pp.207-11.

${ }^{48}$ Soyinka também olha para outras teorias oferecidas para dotar Shakespeare de uma paternidade árabe, e focadas no conteúdo da literatura. "Só um árabe", diz-se, "poderia ter entendido ou retratado um judeu de maneira tão convincente como no Mercador de Veneza. De modo semelhante, a visão de Otelo - a dignidade do Mouro mesmo na loucura é posta como prova convincente de que nenhum europeu poderia criar essa psicologia específica de ciúme complicado por insegurança racial; só um homem por baixo da pele - pelo menos um árabe". ID., IB., p.151. 
Cleópatra (Muneera Mahdia) e Antonio, papel do jovem Muhamad Abdel Wahab, que se tornou o principal cantor/ compositor/ator de cinema egípcio. Como Antonio, Abdel Wahab cantou sua opereta de sucesso "Ana Antunio" [Sou Antonio]. ${ }^{49}$ Sua música de acompanhamento mesclava os quartos de tom árabes com instrumentação ocidental. Enquanto a peça $A$ Morte de Cleópatra focalizava um espírito nacionalista egípcio, a composição revelava a fusão popular entre as tradições musicais árabe e européia e, em última análise, derivava de uma visão sincrética da cultura egípcia.

Em conclusão, parece que a Cleópatra histórica não só ofuscou a desorientou seus amantes, mas também ofuscou $e$ desorientou arqueólogos, egiptólogos, historiadores, artistas, escritores e cineastas. Cada época e cada cultura parece projetar sua própria Cleópatra, visualizando-a de uma maneira nova. Olhar a história das representações de Cleópatra, conseqüentemente, traz muita informação sobre como sua imagem foi "encenada" por diferentes discursos. O fato de que diversos movimentos tenham reivindicado Cleópatra com paixão sugere não só o incrível impacto da rainha na história, mas também as diversas maneiras em que a própria história é filtrada e alegorizada através dos interesses presentes de seus leitores/ escritores. Embora seja importante procurar Cleópatra no registro histórico, é também vital procurar as maneiras como ela e seu mundo foram representadas e configuradas ao longo do tempo. $\mathrm{O}$ desejo de fixar Cleópatra numa única cor, nação, ou raça - numa palavra, numa única identidade - se provará fútil, não só em relação à Cleópatra histórica, mas também em relação ao próprio projeto de imaginar e dar conta do complexo espaço intercultural com que ela está envolvida desde o princípio. As várias interpretações de Cleópatra, como tentei mostrar, revelam de uma

\footnotetext{
${ }^{49}$ Sa'eed Darwish que morreu enquanto trabalhava na peça para compor a música. O jovem Abdel Wahab foi convidado a assumir. Em 1973, escreveu outra canção sobre Cleópatra.
} 
Des-orientar Cleópatra

maneira estranha os métodos discursivos em operação em momentos históricos dados e em dados espaços geográficos. Cada "tomada" de Cleópatra revela não só uma faceta de Cleópatra, mas também uma faceta de quem a representa $e$, mais importante, revela a natureza dos prismas através dos quais Cleópatra foi vista e imaginada. 